\title{
A Tale of Two Maps: A Study of Western Cartographic Practices and Indigenous Pictorial Representation of Varanasi
}

\author{
Gogate, $M$. \\ Graduate School of Asian and African Area Studies, Kyoto University. Kyoto, Japan \\ E-mail: mimawork@gmail.com \\ DOI: https://doi.org/10.52939/ijg.v17i3.1903
}

\begin{abstract}
This paper argues that western cartography notions and practices have rejected mainly the Indian way of understanding the space and its distinct representational approaches. The map-making tradition in India visualises space as organic, complex and connected arrangements, exercises for mapping Varanasi city carried out by the British scholar James Prinsep in 1822, in contrast, relied on mathematical abstraction and land centric ideologies. The consequences of such contrasting styles and methodologies for visualising space, I argue, was made most acutely perceptible in the manner in which the river Gainga was understood and positioned within the respective frameworks. While in western cartographic reckoning Varanasi was considered to be a dry space that was abutting the flowing Ganga river, in the indigenous representational formats the very same space was characterised as being a region where land and water met and interwove a continuum between the fluvial and the terrestrial.
\end{abstract}

\section{Introduction}

This paper analyses how western cartographic practices have mainly visualised and mapped the sacred spaces in India. Varanasi ${ }^{1}$ is one of the few ancient sacred cities in India that has continuously visited, fondly explored, meticulously mapped, intensely written, and documented for more than last two thousand years. Varanasi is one of the most sacred Hindu pilgrimage sites in India (see Figure 1).

In Varanasi, along with numerous inland water bodies, rivulet Varan̄ā and a smaller stream (nālā) named Asī has a confluence with river Gangea at north and south respectively. This distinctive natural setting underpins the notion that water is a widespread phenomenon in Varanasi. Since the water of a celestial river, Gangā is flowing and present everywhere the water of these small and mediumsized water tanks, ponds, wells, and streams are also considered sacred, and thus it forms the sacred water places (tirtha ${ }^{2}$ ). Like other places in India, almost all forms of water reservoirs in Varanasi are closely associated with the pantheon of Hindu deities (Agarwal and Narain, 1997). Most European travellers and colonial officers who travelled to Varanasi after their stay in Calcutta (now Kolkata) or Bombay $^{3}$ (now Mumbai) were influenced mainly with the stark differences they witnessed in Varanasi. Varanasi was quintessentially an Indian city that they heard about, read about, and envisioned before arriving in this prominent pilgrimage place.

This paper focuses on the western map-making exercise and studies in particular, how the intrusion of western cartographic narratives has had a prolonged impact on the views and understanding of Indian spatial visualisation by evaluating two distinct maps of Varanasi. The first map was produced by British scholar James Prinsep (1799-1840). Prinsep arrived in Varanasi in 1820 and lived for the next ten years in the city. Within the first two years of his stay, he surveyed the city and produced an accurate map out of his amusement. This map was titled as "The City of Bunarus ${ }^{4}$, surveyed by James Prinsep" and published in 1822. The map of 1822 produced by Prinsep is in several ways typified how the early colonial authorities came to organise notions of space and geographical order. The western cartographic notion of space, however, as I will point out, was markedly different from that of an indigenous conceptualisation, as evidenced in the following map drawn by unknown mapmakers.

${ }^{1}$ Varanasi is one of the fastest-growing urban centres in Uttar Pradesh state, India. This ancient and continuously living city is located on the west side of river Gangā over a high natural embankment. The Varanasi city had a population of around 1.5 million people, spread across an area of $82.1 \mathrm{sq}$. km with a total 90 wards.

${ }^{2}$ Tîrtha means, a sacred place on the course of sacred streams, place of pilgrimage, sacred water, ford or crossing in a river, etc.

${ }^{3}$ Reynolds-Ball, Eustace (1907) in his travel book "The Tourist's India" writes that Bombay and Calcutta are the "front-doors" of India

${ }^{4}$ Varanasi is also referred as Banaras and was commonly spelt as Bunarus/Benares/Benaras by the Europeans in the colonial documents. 

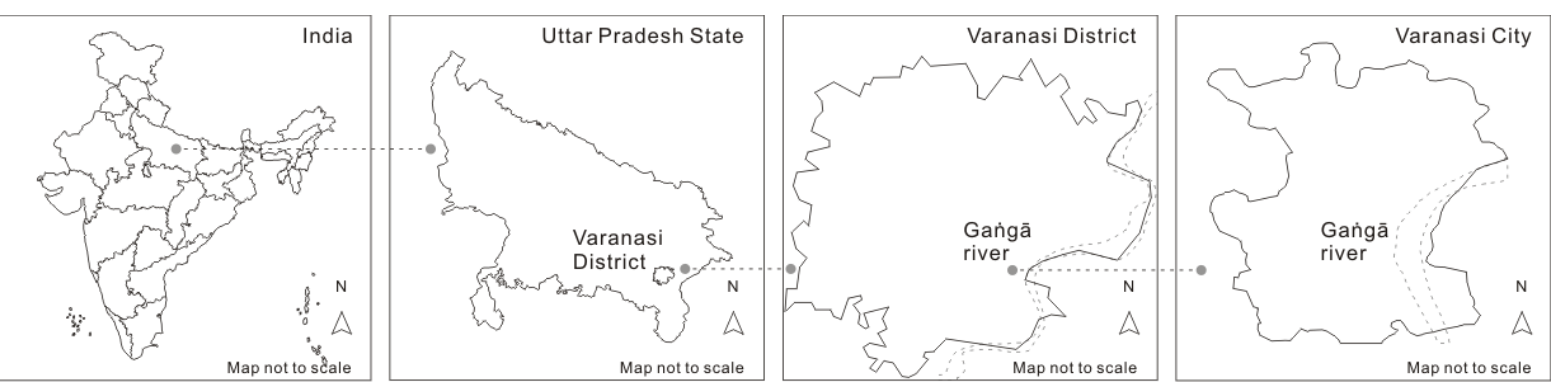

Figure 1: The geographic location of Varanasi city, India. Details: Made by the author. Map not to scale

The second map is, "Map of Varanasi, Shiva's Sacred City" drawn probably in the late 18th century by the anonymous mapmaker. This 18th-century map of Varanasi is a relatively recent discovery and was earlier catalogued by a somewhat misleading title . This "schematic map" earlier had a label describing it as a "pictorial chart" and not as a map". Probably this work was rather acknowledged and evaluated as a painting or a chart and not explicitly as a "map". "Maps are graphic representations", writes Harley and Woodward (1987) after analysing the etymologies of Latin and other European words for the map, "that facilitate a spatial understanding of things, concepts, conditions, processes, or events in the human world." This comprehensive approach marks a significant departure from the notion which ultimately rejected the indigenous pictorial maps.

The two maps discussed in this paper, carefully depict the city dominated by the presence of flowing water and carefully map the diverse water bodies. However, both maps adopt a diverse arrangement to epitomise the numerous water bodies and their existence. The closer review of two maps reveals how mapmakers perceived the dynamic relation of wet and dry.

\section{Colonial Mapping Exercise}

The surveying exercise of Varanasi goes back in 1765 when a Jesuit missionary named Joseph Tiefenthaler (1710-1785) visited Varanasi and did some survey of the course of river Gangā. Later, between 1784 and 1786, Captain Brown of East India Company carried out a survey. After that from 1788 Capt. Francis Wilford (1805) who was serving officer in Bengal Engineers, continued the survey of the Varanasi province. Wilford (1805) was closely associated with Sanskrit language College at Varanasi. Wilford (1805) studied Purāṇa-s and other literary texts with the assistance from a Hindu pandita (scholar) to understand the Hindu cosmography and geography. He wrote an essay in Asiatick Researches which was published in 1805 . In this lengthy essay, he asserted that Hindus seriously lack the notion of history and geography. He further added that even though Hindus have world maps and maps of Indian towns these maps are not drawn by applying a proper scale and coordinates. The rejection of the Hindu notion of geography and carto-literacy emphasised by Wilford (1805) arguably overshadowed the future research on geographic understanding and mapmaking practices of India.

In the book titled "History of Cartography" scholar Bagrow (1964) has argued that India being a "closed country" had a negligible knowledge of geography and dearth of cartography. In his book, Bagrow defined map as a scientific document and map-making as an art of measurement, which requires drawing with a high level of precision. The "scientific document" and "precision" are essential notions that have shaped mainly the western map making practices and become the benchmarks to evaluate any map or chart.

The travelogue of Thomas Twinning published in 1893 is probably an apt example of how the western travellers and colonial officers were perplexed to observe things like astronomy, almanacks, algebra, etc. during their stay in India. Twining (1983) wrote that he had purchased an "accurate map" of Delhi (city) along with some other places and also an almanack. In one instance, Twinning mentions about the detailed direction he received from local people about the routes. However, during his expedition in northern India, Twinning referred to the map of James Rennell and found that the position of 'AllyGunge' (Aliganj) marked by Rennell was incorrect.

${ }^{5}$ For more information about this map see: Gutschow, Niels. 2006. Benares: The Sacred Landscape of Varanasi, and Gengnagel, Jörg. 2011. Visualized Texts: Sacred Spaces, Spatial

Texts and the Religious Cartography of Banaras.

${ }^{6}$ According to the 'object history note' on the website of Victoria and Albert Museum, London, the 19th-century museum label described this as 'Pictorial Chart of Shivapura' (http://collections.vam.ac.uk/item/O434358/painting/) 
Further, he states that though Hindu-s know about astronomy, algebra, and mathematics, they lack the knowledge of geography and medicine. Schwartzberg (1992) has flagged that previous studies on geography and cartography have either overlooked or ultimately rejected the available corpus of South Asian cartography. He referred to the book "Indian Maps and Plans" written by Gole (1989) and acknowledged her work of detailed research and collection of indigenous Indian maps, charts and plans ${ }^{7}$. Jörg Gengnagel (2011) has alleged that western interpretation of the history of South Asian cartography crafted a hypothesis that maps of South Asia were exclusively made only by Western cartographers.

Besides the humid tropical environment, which caused serious trouble of storing the maps, plans and charts, many maps were often discarded by colonial rulers after their usage (Schwartzberg, 1992). This common practice perhaps resulted in the scarcity of Indian maps that compelled the historians and researchers to either dismiss or made a cursory reference to the history of map-making in India. Additionally, the accessible indigenous maps are primarily evaluated based on a modern standard such as scale, proportional representation, and orientation. This rather selective approach has excluded detailed examination of pictorial maps.

Goswami (2004) argued that before the induction of Western maps, there was no equivalent word for the "map", especially in the Sanskrit language. She further criticises that the maps from paurānika works lacked proper scaling and were strangely oriented towards east. She states that the modern western cartography does not allow to manifest the territory in symbolic and ambiguous forms; instead, it combines diverse regions into one single uniform space. However, Harley and Woodward (1987) elucidate that the origin of the word map in late Latin was "Mappa" or "Carta", meaning cloth or a formal document respectively. Sircar (1960) mentions the common word "nakshā" (or naqshā) which comes from the Arabic word has several connotations other than a map. He highlights the Sanskrit word "mānacitra", denoting map, chart, plan, diagram etc. Raj (2007) draws our attention to the fact that many maps of South Asia made by European mapmakers before James Rennell's map (which was first published in 1782) were drawn with varying scale and orientation. Short (2003) explains the Latin word "orientation" and its Latin origin, meaning east. He refers to the medieval period when mapmakers customarily oriented towards the east where Holy Land (Jerusalem) is located. The orientation of a map was influenced mainly by the prevailing cosmographical notions, the favourable direction of rulers and faiths of that particular territory. At the same time, the Church preferred eastward orientation and others such as Arabs and Romans maps drawn facing the South (Birch, 1949). The English maps started orienting the maps toward northern direction happened in the middle of the fifteenth century, and that is probably influenced by the introduction of a land compass (Harvey, 1987).

\section{The First "Accurate" Topographic Map of Varanasi}

In 1820, James Prinsep arrived in Varanasi as Assay Mint Master and started surveying Varanasi out of his interest for two years. He then published his map of Varanasi titled as "The City of Bunarus, surveyed by James Prinsep" in 1822 (see Figure 2). The 1822 map satisfied all the prevailing western cartographic norms and referred to as the first accurate topographical map of the city. The scale of the map was 8 inches to the mile (approx. 1.609 kilometres). However, Gutschow (2006) do not consider this as a "topographical map" because the scale of the map is 1:5000. At the bottom side of the map, there is a north pointer and a slightly tilted vertical line to show the accuracy of north direction. Prinsep has drawn the Tārakeśvara temple placed on the Maṇikarṇikā ghāṭa of river Gangā as a cartouche. Below this cartouche, he stated the locations of the main Hindu temples. On the top right corner of the topographical map, Prinsep provides a list of main festivals and the locations of police offices in the city. In the right bottom side of the map, Prinsep provided the detailed map of the "Cantonment" area in the northern part of the city called Secrole (Sikraul). In the left bottom, Prinsep described the legends of his topographical map and provides the information about Varanasi city, such as roads, alleys, brick houses, mud houses, muhallā (ward), bāzāra (marketplace), etc. While working on this topographical map, Prinsep also carried a census of the city. His census provides a list of 1,000 Hindu temples, 333 mosques and 174 gardens. The 1822 map reveals some of the meticulous survey work carried by Prinsep. Gutschow (2006) describes this map as "a priceless document" that appropriately manifests the urban city before two hundred years.

The map of 1822, with fewer variations, can be georeferenced on the satellite imagery (see Figure 3) and thus it depicts the detailed observations and surveys efforts carried by Prinsep. Prinsep has mentioned the names of all ghăța (masonry stairs on the riverbank) beginning from the south towards north on the west side of river Gangā.

${ }^{7}$ Gole, S., 1989, Indian Maps and Plans: From Earliest Times to the Advent of European Surveys. 


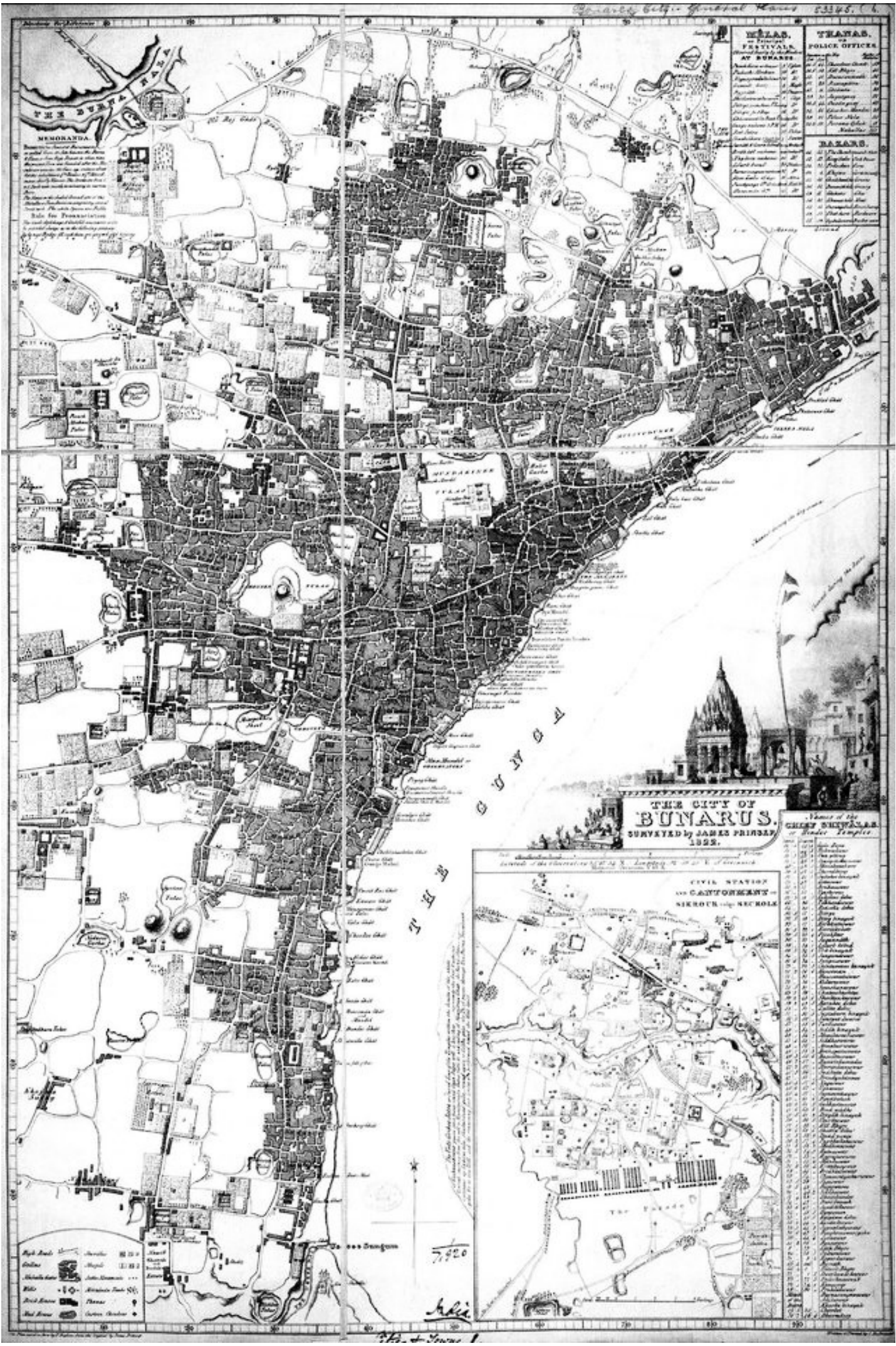

Figure 2: The city of Bunarus. Surveyed by James Prinsep. 1822. London: British Library. Details: Size, 74 by $48 \mathrm{~cm}$ 


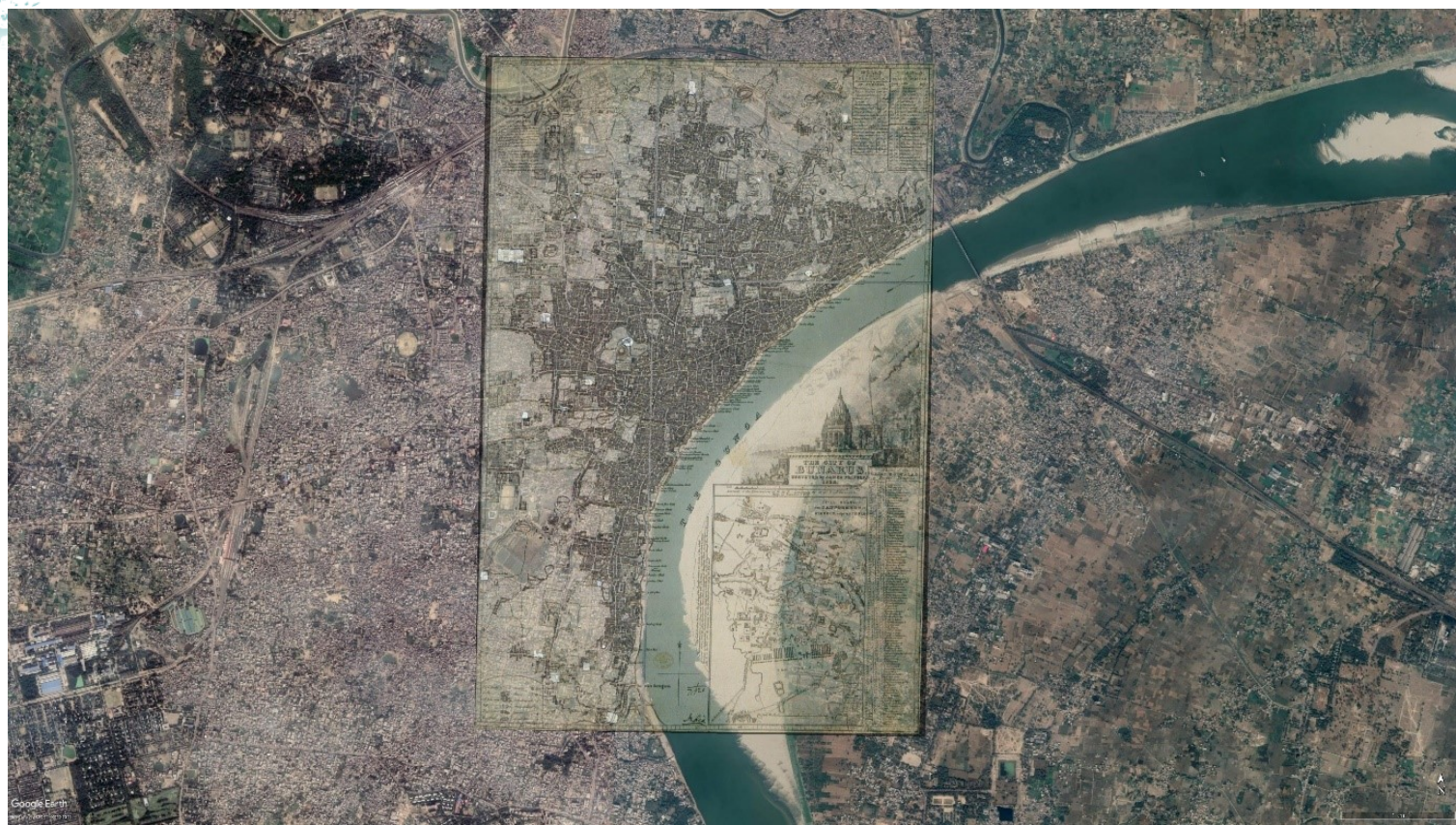

Figure 3: Georeferencing of the map - The City of Bunarus. Surveyed by James Prinsep 1822 on the satellite imagery (Google Earth). Notes: Made by the author, QGIS version: 2.18.7. Notes: Map not to scale

The map also illustrates river Gangā and its channel during the dry and in monsoon season to reveal the variation in water level. In the left top corner Prinsep drawn Varan̄a river and labelled it as "The Burna Nālā"». Prinsep also mentioned the Asī rivulet as 'Ussee Nala' towards the south and its confluence with river Gangā. Likewise, the names of ghāța Prinsep mapped the total 61 titled sacred temple tanks, ponds ${ }^{9}$ and several wells of Varanasi (see Figure 4). I have mapped both the titled and untitled water bodies (excluding the wells) on the map of 1822 to explore and study the dynamic waterscape of the urban city. The tracing of water bodies reveals the size and drainage system of the city in 1822 . The 1822 map sufficiently provides the land and water equation and how the excess water flows from different channels. When Prinsep mapped the city, possibly the Agastya Kuṇụa and Bula Nālā were extinct. However, Prinsep marked the possible location of these two water reservoirs on his map.

\subsection{Land and Water Separation}

The map of 1822 surveyed by Prinsep is a landcentric representation that follows all the cartographic yardsticks and thus enjoys the reputation of the first accurate and modern map of the city. It reveals all the information that its reader seeks, who is conversant with basic principles of cartography. The map provides information such as street patterns, types of housing structures, gates, etc. based on the actual survey carried by Prinsep.

The 1822 map also has a table of legend to which Prinsep tagged "General References" to explain the symbol used in his map. The reader of the map consequently recognises how the mapmaker has confined the vast territory on the paper in twodimensional form. The 1822 map markedly embodies the city is placed adjoining the principal river, and thus the river appears as a dominant element. The map subtly reveals the land and water separation and distinguishes the dry and wet attributes of the topography. Prinsep delineated the area around some of the water bodies with a dotted line to indicate that this specific area gets inundated during the rain. The representation of water is purely in the secular form and appears as a resource, whereas the land represents the notions of property. Pieper (1979) has compared the Prinsep's map of 1822 with one another pictorial map titled "Pilgrims' map of Benares" drawn in 1875. He flags out the main objectives of the 1822 map was to aid the administrative and military requirements. Therefore, the "public accessibility" and "general significance" of the place is effectively displayed without concerning the sanctity of the place.

${ }^{8}$ Nālā is translated as a small stream. However, the post-1822 colonial maps labelled Varanāa as a river.

${ }^{9}$ Mapped and identified by the author 


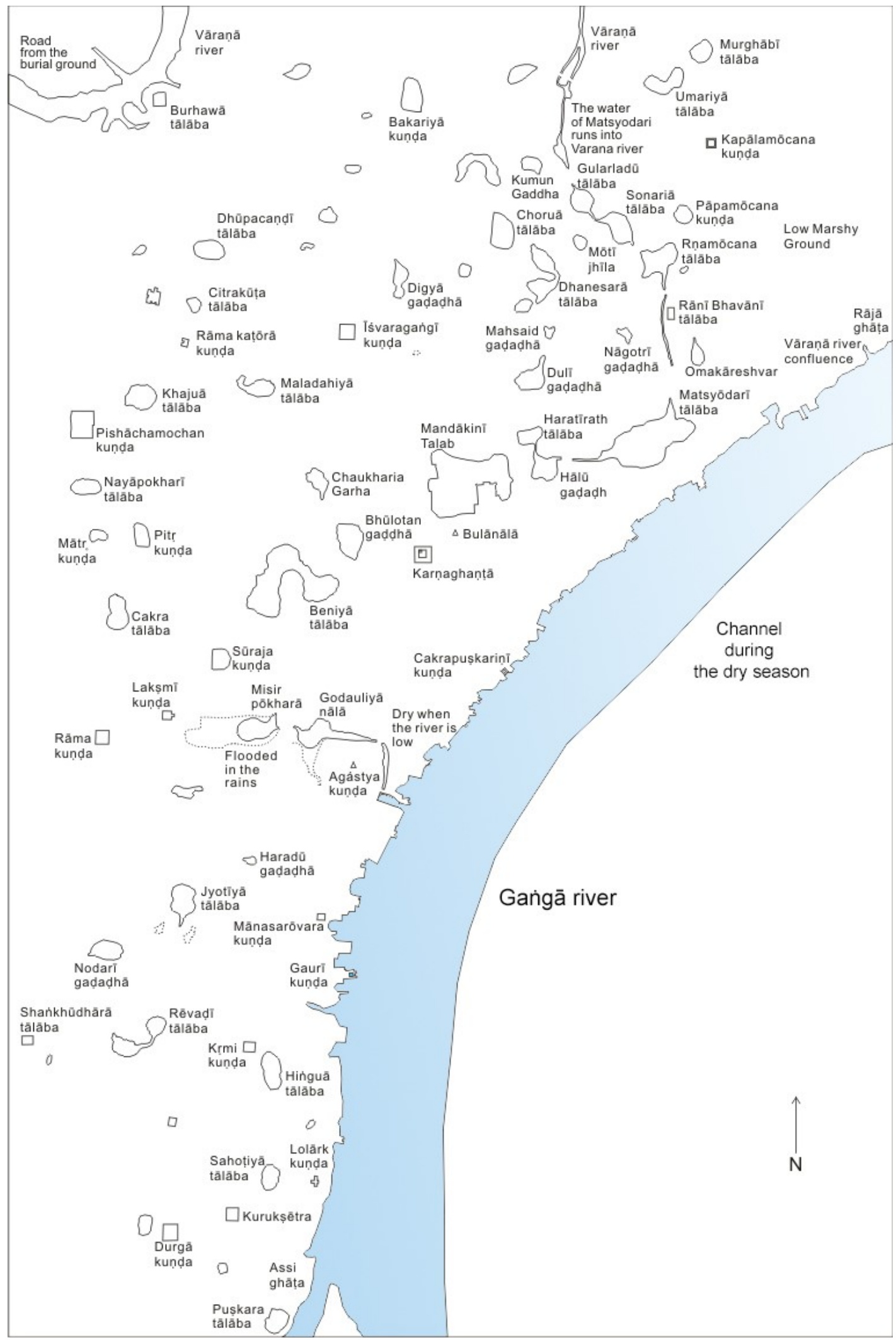

Figire 4: Tracing and reduction to water bodies (excluding the wells) of the map - The City of Bunarus, surveyed by James Prinsep. 1822. Notes: Drawing by the author. Map not to scale 


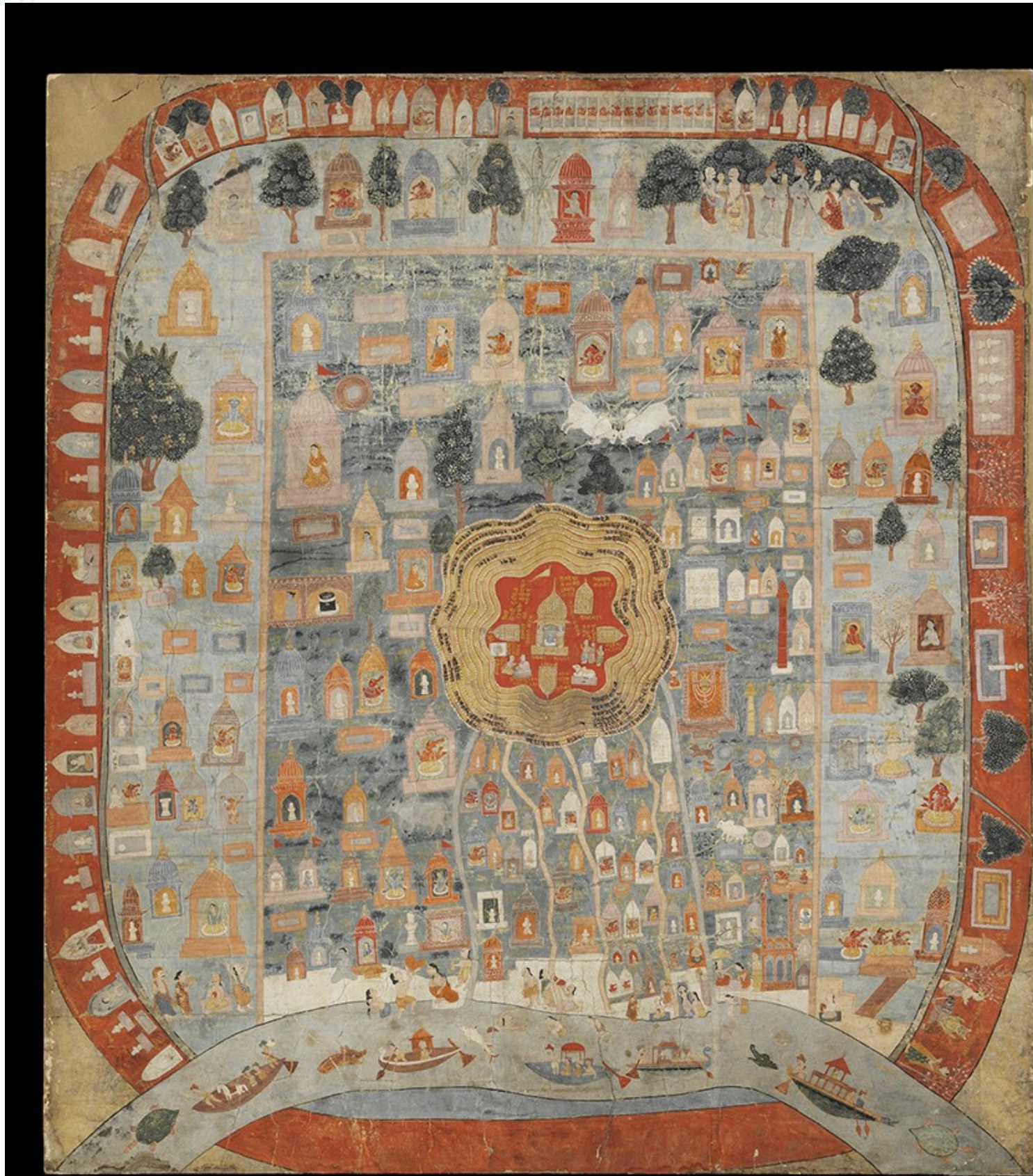

Figure 5: Map of Varanasi, Shiva's Sacred City. Notes: The Victoria and Albert Museum. London. Details: Size, 108 by $98 \mathrm{~cm}$ (in frame), painting on cotton

\section{Pictorial Map of Varanasi}

This map was previously titled as "Pictorial Chart of Shivapura. The heavenly city of Shiva" at the Victoria \& Albert Museum London. The present title of this coloured map is "Map of Varanasi, Shiva's Sacred City" (see Figure 5) dated 18th century. Gutschow first time discussed this map and referred this as "Victoria \& Albert Museum picture map". However, Gengnagel has proposed the title "Stylised map of Varanasi". I propose the name, "Pictorial Map of Varanasi" and after interpreting the basic layout of the map will elaborate on the water structures of the map, which is not yet sufficiently explored and discussed. James Prinsep and an anonymous 
mapmaker both has surveyed the water bodies and depicted it on the map. The pictorial map of Varanasi is Westward oriented, and river Gangā is depicted on the bottom side, i.e. to the east side. River Varaṇa depicted on the right side (north) and Asī rivulet at the left side (south) of the map. The temple of Viśvēśvara or Viśvanātha and the main complex is located in the centre of the map surrounded by yellow colour eight circles with smooth curved on eight directions which constitutes the Antarg̣̣ha kșêtra (innermost circuit). Immediate outside of the central eight circles, enclosed by thin line is the area referred to as Avimukta kșetra (the place is never forsaken by Siva; the principal deity of Varanasi). There are also five streams flowing down from the Antargṛha kṣētra and joining the river Ganga at the bottom. The five streams are called as Pañcanada (five rivers; Dhūtapāpā, Kiraṇā, Gañgā, Yamunā and Sarasvatī). These rivers are the symbolic representation of rivers that appears in Purāna-s. Outside of Avimukta kṣētra area is referred to as Kāśí1 ${ }^{10}$, and the outermost area is called as Pañcakrōśī mārga (route) (Gutschow, 2006 and Gengnagel, 2011).

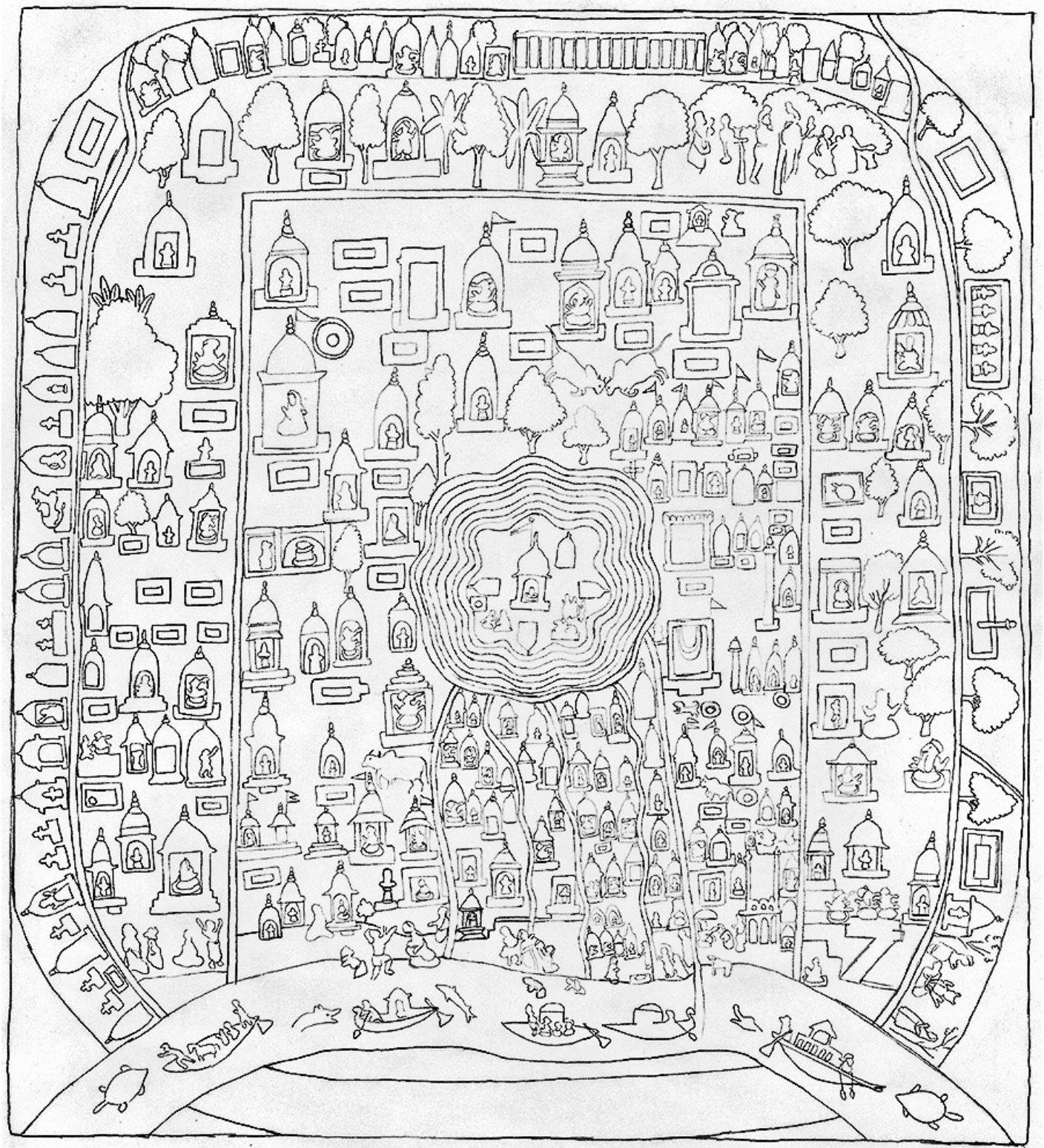

Figure 6: Tracing of all the visible forms on the Map of Varanasi, Shiva's Sacred City (The Victoria and Albert Museum. London). Notes: Drawing by the author (not drawn to scale). An attempt of tracing of all visible forms is made to map the water bodies, their titles and total numbers

${ }^{10}$ Sukul (1977) draws our attention to the fact that in the last millennium, the territory of Kāśī and Varanasi became somewhat equivalent. However, prior to that Kāśi region was bigger than Varanasi region. 


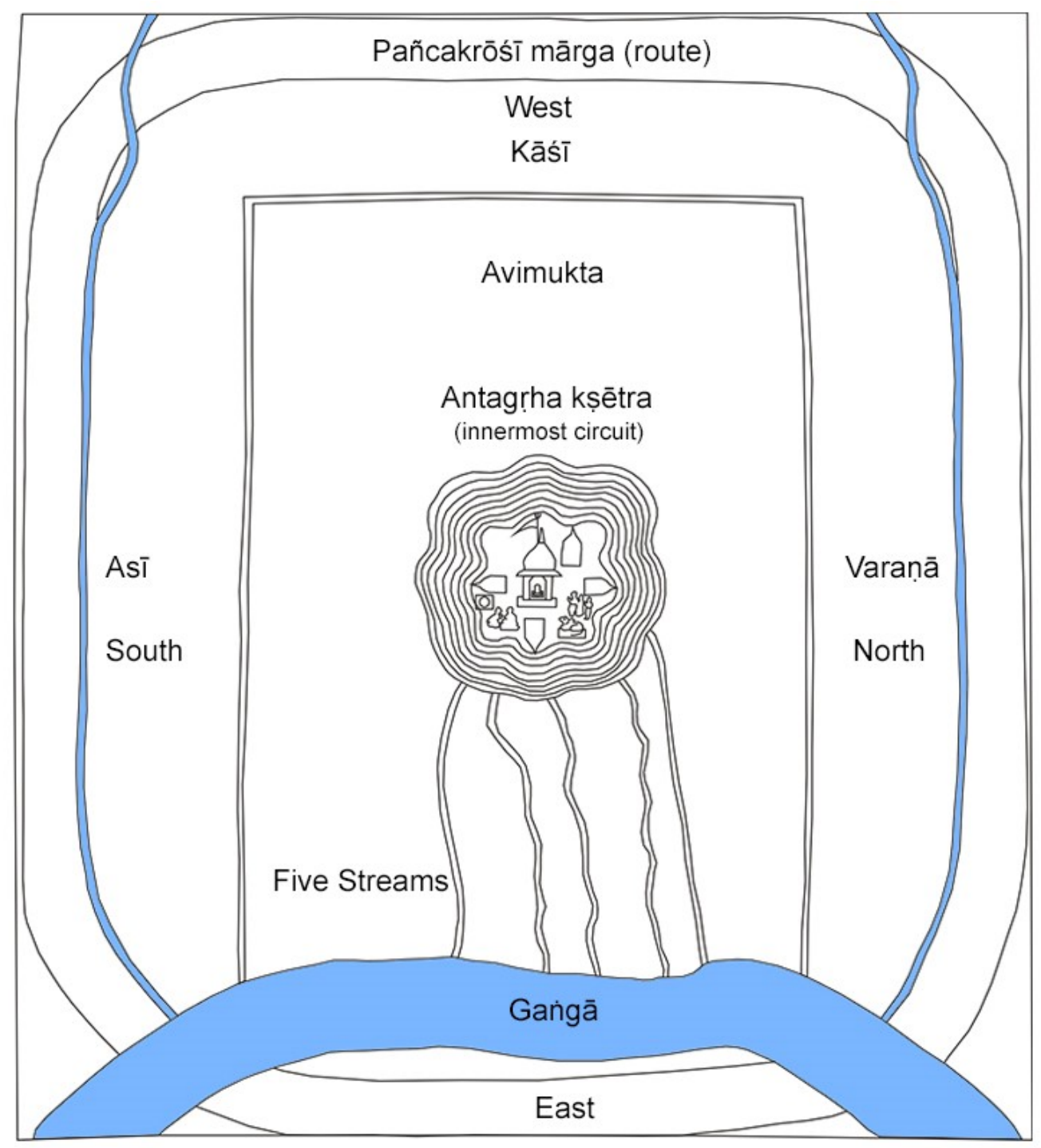

Figure 7: Tracing of main zones and their titles (including river and rivulets) on the Map of Varanasi, Shiva's Sacred City (The Victoria and Albert Museum. London). Notes: Original drawing by Gutschow Niels (2006).

Tracing and editing by the author. Map not to scale

The map does not provide any navigational information or the detailed location of the temples and water pools. No primary importance or preference has been given to any temple. The depiction of Kāśī Vishwanath temple is also not exceptional, except it is depicted in the centre of the map (see Figure 6 and Figure 7). Gengnagel (2011) has given a detailed description of the temples and temple tanks and described the map in five sections based on the boundaries of the territory. To discuss the spatial distribution and arrangement of forms, I mainly focus on the sacred temple tanks and ponds depicted on this map mainly for two reasons. First, Gutschow and Gengnagel both have not mainly focused on the water reservoirs. Secondly, these water bodies are not used only for mundane activities. Instead, they are part of the greater temple complex and the water in these tanks and ponds is as sacred as the venerated deity inside the temple. The mapmaker, along with the titles, has mentioned the attributes of the water structures. Based on their attributes, features and structural forms, I classify these temple tanks and ponds into nine categories based on (see Figure 8). The mapmaker has drawn the shape and other architectural forms as described in the Purāna-s and other literary texts. The nine categories represent the diverse forms of water bodies and their locations corresponding to other water pools and temples. 


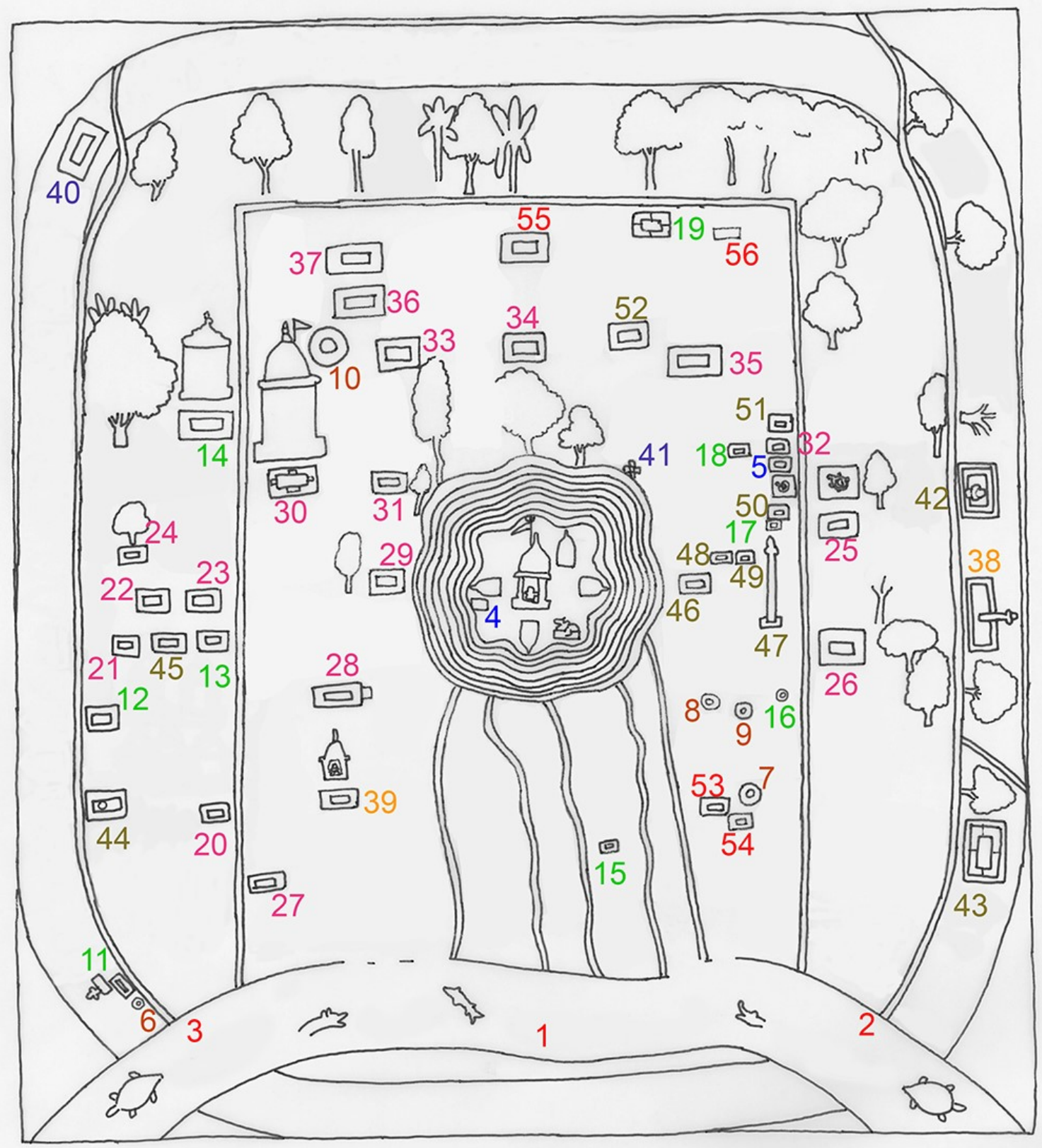

Figure 8: Tracing of all the sacred water bodies (including the two rivulets and one river) on the Map of Varanasi, Shiva's Sacred City (The Victoria and Albert Museum. London). Notes: Drawing by the author. (For more clarity, the nine groups of water bodies are marked by separate colours). Map not to scale.

The nine distinct categories demonstrate the spatial understanding of the mapmaker and his unique approach to locating these water bodies according to the zones of the sacred city. The mapping of these water structures provides the existence of various water forms and can be used as a data point to analyse the transformation.
Group 1. River and rivulets: 1. River Gañgā, 2. Varanā sangama (confluence of river Varaṇā with river Gañgā), 3. Asī sangama (confluence of Asī rivulet with river Gangāa)

Group 2. Vāpī (a well with steps): 4. Jñān vāpī 5. Karoțaka vāpī 
Group 3. Kūpa (a round well without steps): 6 . Kardama kūpa, 7. Oṁkāra kūpa, 8. Mahakala kūpa, 9. Vrddhakala kūpa, 10. Kamaksi kūpa

Group. 4. Tìrtha (a sacred stream, river, place in the vicinity of sacred spring): 11. Kardama tīrtha, 12. Puṣkara tīrtha, 13. Sannihita tīrtha, 14. Shan̉khūdhārā tīrtha, 15. Cakrapuṣkariṇi tīrtha, 16. Ratnacudamani tirtha, 17. Vaitarani tirtha, 18. Mandakini tirtha, 19. Vimala tirtha,

Group 5. Kuṇda (a water reservoir with oblong shape): 20. Hanumadi kuṇ̣a, 21. Durga kuṇụa, 22. Renuka kuṇụa, 23. Krmi kunda, 24. ...kuṇụa (no identification), 25. Vasuki kuṇda, 26. Bakariyā kuṇḍa, 27. Gaurī kuṇụa, 28. Rēvā kuṇụa, 29. Lakșmī kuṇ̣a, 30. Kāmākṣī kuṇụa, 31. Lavakusa kunda, 32. Dadhavi kunda, 33. Surya kunda, 34. Pitru kunda, 35. ...tra kunda (not identified), 36. Matra kunda, 37. Varahi kunda

Group 6. Sarōvara (a lake or a large pond): 38 . Yupa Sarōvara, 39. Mana Sarōvara

Group 7. Sāgara (a sea, or a pond): 40. Gandharva sāgara, 41. Tata sāgara

Group 8. Untitled: 42. Prthvisvara, 43. Kāpiladhāra, 44. Lolārka, 45. Kurukșetra, 46. Rnamocana, 47. Lāt Bhairava ${ }^{11}$, 48. Papamocana, 49. Kapalamocana, 50. Tarni (uncertain), 51. Isvaragangi, 52. Ghantakarna

Group 9. No description: 53 (blue rectangular tank), 54, 55. (red rectangular tank), 56. (small rectangular tank)

\subsection{Water Sensitive Mapping}

The 18th-century pictorial map of Varanasi city depicts 183 temples (Gutschow, 2006) and 56 distinct types of water structures (mapped by the author). These water structures include - principal river, rivulets, wells, lakes, ponds, and water pools of different shapes. The water tanks mentioned in Group 8 are subtitled as ponds, water reservoir, tanks, wells, etc. in other works of literature. Three water structures under the (Group 9) are having no description (Gengnagel, 2011).

Gengnagel (2011) has argued that the mapmaker most likely as a visitor and not a resident of Varanasi. The reason Gengnagel states that mapmaker has not mapped the lofty and striking riverbank and nearly failed to portray the spatial understanding of the city. However, the pictorial map of Varanasi effectively explains the geomorphological features of the city with one principal river flowing from south to north, tributary, small stream and gathering of inland water tanks and ponds. Mapmaker has captured the modest slope of the tract from west to east direction and probably oriented the map to the westward direction. The map also subtly depicts the natural flow of water and the fluid nature that dominates the landscape of the city. It successfully captures the movements of the water and highlights the catchment ecology.

\section{Concluding Remarks}

According to Guan (1992), cartographer creates a visual presentation which is not necessarily confined to two-axis but how we feel the physical environment around us. Eck (1998), elucidates that the potential of "imagined landscape" constructed by mapmakers captivates more attention than the western scientific map. James Prinsep's map of 1822 is a topographical map, a map that essentially depicts the physical milieu (Birch, 1949). Even though, Prinsep has shown the location of temples and also marked the dotted line to depict the Antargṛha kșetra (innermost circuit) the central feature of this map is an empirical representation of the colonial city. Prinsep's map does not require any supplementary knowledge or context to observe the map. The first-time visitor to the Varanasi city can effortlessly locate the places on this two-centuries-old map after a careful glance.

However, in the case of the pictorial map of Varanasi, it is not intended as a guide map. Instead, it is an assemblage of all celestial edifices that harmonises with the surrounding natural landscape of the city. To read the pictorial map of Varanasi, you need to read the supplementary texts. It is a dynamic representation that subtly blends the physical and spiritual forms which both cartographer and devotees are aware of. He has translated the spatial texts that discussed the geography of Varanasi into the pictorial format. The two distinct maps discussed in this paper, juxtapose the fundamental perception to see the land and water ecology and their interconnection. The pictorial map of Varanasi with its westward orientation possibly hints to the natural slope from west to east and a natural embankment on river Gañgā. The peculiar arrangement of the various sacred zones and the water pools point out that the mapmaker probably aware of the Purāna-s and other literary texts that provide detailed spatial information about the region. He therefore possibly oriented the map westward to depict the gradual gradient and the drainage pattern of the city. The map reveals the continuum between fluvial and terrestrial. 
Prinsep's map of 1822, is an archetype of western mapping where scale, dimensions, orientation, and careful surveys are vital benchmarks that provides the foundation to produce an accurate representation of the city. It is an objective representation of the urban centre with an intention for the colonial administration and control. Prinsep's map of 1822 subtly reveals the trajectory of the survey of land and revenue system with its underpinnings of land as a fixed and property notion while water as a mere resource. The 1822 map is a land centric imagination that separates the land and water and shows the rigid boundaries of these two elements.

Notes: The English translation of the 'Skanda Purāna - Kāśí Khaṇụa' (Tagare, 1996-1997) has been the basic source for the study and for making the catalogues of temple tanks and ponds of Varanasi. However, the Sanskrit-Hindi translation text is additionally referred to verify the titles and other information.

\section{References}

Agarwal, A. and Narain, S., 1997, Dying Wisdom: Rise, fall and Potential of India's Traditional Water Harvesting Systems (eds), New Delhi: Centre for Science and Environment.

Bagrow, L., 1964, History of Cartography (Revised and enlarged by Skelton, R. A.). London: C. A. Watts and Co. Ltd.

Birch, T. W., 1949, Maps: Topographical and Statistical. (London: Oxford University Press).

Eck, D. L., 1998, The Imagined Landscape: Patterns in the Construction of Hindu Sacred Geography, in Contributions to Indian Sociology, Vol. 32(2), 165-188.

Gengnagel, J., 2011, Visualised Texts: Sacred Spaces, Spatial Texts and the Religious Cartography of Banaras, (Wiesbaden: Harrassowitz Verlag).

Gole, S., 1989, Indian Maps and Plans: From Earliest Times to the Advent of European Surveys, (New Delhi: Manohar Publications).

Goswami, M., 2004, Producing India: From Colonial Economy to National Space, (Chicago: The University of Chicago Press).

Guan, K. C., 1992, Cosmography and Cartography. SPAFA Journal, Vol. 2(1), 12-16.

Gutschow, N., 2006, Benares: The Sacred Landscape of Varanasi, (Stuttgart/London: Edition Axel Menges).
Harley, J. B. and Woodward, D., 1987, The History of Cartography, Vol. I, Cartography in Prehistoric, Ancient, and Medieval Europe and the Mediterranean (eds.). (Chicago: University of Chicago Press).

Harvey, P. D. A., 1987, Local and Regional Cartography in Medieval Europe, In; Harley, J.

B. and Woodward, David. (ed.)., The History of Cartography, Vol. 1, Cartography in Prehistoric, Ancient, and Medieval Europe and the Mediterranean, (Chicago: The University of Chicago Press), 464-501.

Pieper, J., 1979, A Pilgrim's Map of Benares. Notes on Codification in Hindu Cartography. GeoJournal, Vol. 3(2), 215-218.

Raj, K., 2000, Colonial Encounters and the Forging of New Knowledge and National Identities: Great Britain and India, 1760-1850. Osiris, Vol. 15, 119-134.

Reynolds-Ball, E., 1907, The Tourist's India, (London: Swan Sonnenschein \& Co).

Schwartzberg, J. E., 1992, Introduction to South Asian Cartography, in Cartography in the Traditional Islamic and South Asian Societies. The History of Cartography, Harley, J. B., and Woodward, David. (eds.) 2- 1, Chicago: The University of Chicago Press.

Short, J. R., 2003, The World Through Maps: A History of Cartography. Toronto: Firefly Books).

Sircar, D. C., 1960, Studies in the Geography of Ancient and Medieval India. (Delhi: Motilal Banarsidass).

Sukul, K. N., 1977, Varanasi - Vaibhav (The Glory of Varanasi), (Patna: Bihar-RashtrabhashaParishad).

Tagare, G. V., 1996-1997, Skanda Purānaa, Translated and annotated by G.V. Tagare, Käśí Khanda, Two Volumes, (Delhi: Motilal Banarsidass).

Twining, W., 1893, Travels in India a Hundred Years Ago with a Visit to the United States: Being Notes and Reminiscences. Being Notes and Reminiscences by Thomas Twining (ed.), (London: James R. Osgood, Mcllvaine \& Co).

Wilford, F., 1805, An Essay on the Sacred Isles in the West, with other Essays Connected with that Work. Asiatick Researches, Vol. 8, 245-375. 